4. Токарчук О. Чуткий рассказчик: нобелевская лекция. 2019. URL: https://www.colta.ru/articles/literature/23214-olga-tokarchuk-nobelevskaya-lektsiya-polnyy-tekst (дата обращения: 8.04.2021).

5. Токарчук О. Бегуны / предисл. Э. Худобы; пер. с польского И. Адельгейм. Москва: Новое литературное обозрение, 2010. 404 с.

6. Bye S. G. Flights by Olga Tokarczuk. Book Reviews. 2018. URL: https:// www.worldliteraturetoday.org/2018/july/flights-olga-tokarczuk (дата обращения: 18.04.2021).

7. Flood A. Olga Tokarczuk's 'extraordinary' Flights wins Man Booker International prize. 2018. URL: https://www.theguardian.com/books/ 2018/may/22/ olga -tokarczuk -flights-wins-man-booker-international-prizepolish (дата обращения: 19.04.2021).

DOI https://doi.org/10.30525/978-9934-26-073-5-1-35

\title{
СИМВОЛІКА ГЕРОЇЧНОГО В УКРАЇНСЬКІЙ НАРОДНІЙ ДУМІ «ІВАН КОНОВЧЕНКО»
}

\author{
Набок М. М. \\ кандидат філологічних наук, \\ дочент кафедри мовної підготовки іноземних громадян \\ Сумського державного університету \\ м. Суми, Украӥна
}

Етимологія слова «символ» бере початок від грецького іменника unmbolon, що означає 'знак', 'прикмета', а дієслово з таким же коренем у перекладі означає «з'єднувати, зіштовхувати, порівнювати» [2, с. 738]. Символіка, як поняття етногенетичне, у фольклорних творах допомагає нам зрозуміти спосіб мислення наших пращурів, їх моральні, духовні, етичні й естетичні ідеали. В основу змісту категорії «героїчне» покладено принцип співвідношення реальності та ідеалу [3]. Українському народу властиве мужнє сприйняття життя, що синтезувало у собі внутрішню гармонію і героїчний дух. Відчуття спільної волі, належності до окремої нації із спільними віруваннями, традиціями, думками виражено в ідеї патріотизму, вшанування предків, слави.

У думі «Іван Коновченко», образ Cтепу постає як чинник «селекції» [5, с. 55]. Суспільство, яке пасивно спостерігало та визискувало перед ворогом, передавало таку ж модель поведінки своїм нащадкам, активна ж частина народу чинила опір та гинула в боях. У всіх варіантах думи «Іван 
Коновченко», мати не хоче відпускати єдиного сина на війну, проте молодий козак вважає за честь краще воювати, ніж вирощувати хліб. Тому на заклик полковника Філоненка «Гей козакы, панове молодци! / Ще которимъ не хочецца по вынныцяхъ горилокъ курыты, / Ще которимъ не хочецця по броварняхъ пывъ варыты, / А ще которимъ не хочецця за чарку горилкы шинкарци воза дровъ порубаты, / То ходите зо мною, / До Хвылона, корсунського полковныка / На Черкень-Долыну погуляты / И славного лыцарства козацького-молодецького зажываты» $[4$, c. 44], козак вибирає не розгульне життя, а козацьку честь і славу. Естетизація вищої ідеї у думі символічно зображена у порівнянні із життям хлібороба, яке $\epsilon$ принизливим для молодого Коновченка. Зокрема він не хоче, щоб його бабієм, гречкосієм, а коня приблудою називали, бо ж «Тяжко мені, мати, по боронах ходити, / Сапйанові чоботи топтати, / Закоблуки викривляти, / А честь би то мені, мати, / Піти міждо друзи панове погуляти» [4, с. 42], - говорить Іван Коновченко матері. Тож, для козака ідеальний світ - це шлях у степ, поле, бо саме там його дім. Якщо у багатьох переказах та казках наскрізним образом є образ трьох доріг (хто поїде прямо - той буде в голоді, хто поїде праворуч - той буде живий, але кінь загине, поїде ліворуч - буде вбитий, але кінь залишиться живий і т. д.), то у думах героїчного циклу дорогу (шлях) герой визначає сам: шлях в степ постає для нього як цінність буття, бо він самою своєю природою вкорінений у цю землю. Тому й мотив козака Коновченка піти «слави доставати» теж потрактовуємо як цінність, що формує «образ самого себе» й визначає подальші дії і вчинки героя думи. «Образ самого себе» має свої іманентні (властиві, притаманні) закони - культурні ідеали, культурну поведінку, родове ідеальне. У думі «Іван Коновченко» вони зображені крізь призму символічного образу Дому, але не як символу сімейного благополуччя й багатства, а як сакрального ідеального простору в якому виховується, утверджується та передається ідея боротьби від покоління до покоління. Ця ідея у думі символічно втілена у батьківській зброї, що знаходиться у кімнаті. Тому цілком природно, що тут не пахне хлібом:

Ивась Коновченко одъ сна пробужае,

По двору похожае

И смутку соби превелыку мае.

У хату вхожае,

Кимнату видчыняе,

Батькивську шаблю зь килка здыймае.

$[4$, c. 45$]$. 
У варіанті думи, записаної від кобзаря І. Крюковського в Лохвиці 20 травня 1876 р., Іван Коновченко входить до світлиці, як сакрального родового простору, де мати попередньо заховала від сина батьківську зброю, але яку він все ж таки знаходить у запічку, і це теж символічно вказує на вкорінення та невикорінення духу воїнства у родині:

То Йвась Коновченко од сна встає,

У світлицю вхожає,

По стінах поглядає,

Що вже батьківської рушниці на стіні ніодної немає,

Тілько в запічку семип'ядная пищаль сіяє.

То він то коло неї собі козацький звичай

добре знає,

Та до Корсунського полковника

На Черкень долину за сімсот верст поспішає.

$[4$, c. 59$]$.

Дім, світлиия - психологічні синоніми у вираженні особливостей національного світосприйняття i світорозуміння. Поняттям світла пройнята низка фундаментальних понять українського менталітету: CBIT, CВITлиця, всеСВIT, СВIТогляд, СВIТозарний, СВIТочолий і т. п. Світло символізує першотворення світу, життя, істину, джерело достатку [1, с. 497-498]. Тому світлиця у думі - символічний образ зображення i вираження життєдайного простору, в якому виховуються на козацьких звичаях і традиціях. Особливим і незамінним атрибутом цього простору $\epsilon$ зброя, яка теж випромінює світло (у варіантах дум «семип'ядная пищаль сіяє», «на стіні аж отечеськая шабля висить аж сяє» та ін.).

Таким чином, крізь призму пізнання зовнішнього через внутрішне, образи Степу, Шляху, Дому в українській народній думі «Іван Коновченко» поглиблюються у змістовій, ідейній формі. За цього Степ символічно потрактовується як безмежний простір для організації спротиву та боротьби за власне самовираження. Образ Дому тут символічно виражений сакральним ідеальним простором, у в якому виховується та передається ідея боротьби від покоління до покоління. Саме на таких національних підставах ми маємо виховувати молоде покоління, щоб не допустити морального, духовного та ідейного винародовлення. 


\title{
Література:
}

1. Войтович В. Українська міфологія. Енциклопедія народних вірувань. К.: «ФОП Стебеляк», 2014. 692 с.

2. Енциклопедичний словник символів культури України / за заг. ред. В. Коцура та ін. Корсунь-Шевченківський, 2015. 912 с.

3. Набок М., Амлєх С. Категорія «героїчне» у міжетнічному вимірі. Мова, історія, культура у лінгвокомунікативному просторі: збірник наукових праць Випуск 3. Суми: Сумський державний університет, 2016. C. 37-44.

4. Українські народні думи. Тексти № № $14-33$ і вступ Катерини Грушевської. Харків; Київ: Пролетар, 1931. Том другий корпусу. 304 с.

5. Янів В. Нариси до історії української етнопсихології. Мюнхен: Український вільний університет, 1993. 217 с.

DOI https://doi.org/10.30525/978-9934-26-073-5-1-36

\section{СИМВОЛІКА ПОВІСТІ I. ФРАНКА «ВОА CONSTRICTOR»}

\author{
Немченко Г. В. \\ кандидат філологічних наук, доцент, \\ співробітниця наукової лабораторії \\ «Украӥнська література в англомовному світі» \\ при Херсонському державному університеті \\ м. Херсон, Украӥна
}

Одним із найзагадковіших у доробку I. Франка є твір «Boa constrictor», над яким він працював тривалий час. Відомі різні редакції повісті: 1878, 1884 і 1907 pp. Твір неодноразово ставав об'єктом дослідження у працях таких науковців, як I. Басс, Л. Безуглий, В. Власенко, Р. Голод, І. Грицютенко, Т. Гундорова, Т. Денисова, I. Денисюк, Ю. Кобилецький, П. Колесник, Ю. Кузнецов, Л. Терешко та ін. Зокрема проводились паралелі між Франковою повістю та текстами Е. Золя (І. Басс), Ф. Норіса (Т. Денисова) та К. Шпіндлера (Р. Голод).

Повість I. Франка «Воа constrictor» кваліфікують як психологічну, натуралістичну, з елементами символізму. Назва твору акумулює його ідейний зміст і композиційні особливості. Символічний образ зміяполоза $є$ лейтмотивним у повісті. Використовуючи прийом біографічного сюжету, автор простежує життя головного героя Германа Гольдкремера від дитячих літ до зрілості. Історія мільйонера подається через спогади, 